\title{
Typology of Outdoor Seating Areas of Restaurants Based on Factors Influencing Their Thermal Comfort. A Case Study of Pilsen City Centre, Czechia
}

\author{
Václav VÍT', Jan KOPP*1 \\ ${ }^{*}$ Corresponding author \\ ${ }^{1}$ University of West Bohemia, Faculty of Economics, Department of Geography, Pilsen, CZECHIA \\ E-mail: kopp@kge.zcu.cz \\ DOI: 10.24193/JSSP.2019.2.06
}

https://doi.org/10.24193/JSSP.2019.2.06

K e y w o r d s: Beergarden Days, climate adaptation, outdoor restaurant, outdoor climate, thermal comfort, urban microclimate

\begin{abstract}
A B S T R A C T
Due to climate change, the question of thermal comfort in cities is becoming more important in Central Europe. The aim of the study is to design and experimentally verify the typology of outdoor areas of restaurants in terms of their thermal comfort factors, based on a case study of Pilsen's city centre. The research carried out in 2017 in the city centre of Pilsen investigated what means are used by restaurants to improve thermal conditions and how the location of an outdoor restaurant in an urban area affects its thermal comfort. There were forty-three outdoor areas of city centre restaurants included in the proposed typology, based upon their location. The relevance of typology was verified using a selected set of fourteen outdoor restaurant areas. They were evaluated according to the availability of means for comfort enhancement and experimental measurements of relevant meteorological elements. Type 1 (Square restaurant) exhibited the highest air and surface temperatures. In contrast, Type 2 (Courtyard restaurant) showed the lowest air and surface temperatures and Type 3 (Park restaurant) showed the highest air humidity. Type 4 (Street canyon restaurant) had similar temperatures to Type 1, and air humidity was closer to Type 2. According to the number of Beergarden Days, the days when the air temperature at 9 p.m. was higher than $20{ }^{\circ} \mathrm{C}$, the best conditions for sitting outside throughout the year occur from the second half of June to the end of August. The results of the study can contribute to an improvement in the thermal comfort of customers of outdoor restaurants in cities, especially with regard to the choice of locations of outdoor restaurants and the use of elements that influence thermal comfort.
\end{abstract}

\section{INTRODUCTION}

The question of thermal comfort is becoming relevant for the Central Europe cities, given the growing impacts of urban heat islands in a period of climate change (Geletič and Vysoudil, 2012). Planning adaptation measures in urban public space is an important issue for urban planners (Luca, 2017; Slach and Ježek, 2015). Outdoor restaurant spaces represent special areas that should be planned with regard to the thermal comfort of visitors (Égerházi et al., 2009).

The notion of the thermal comfort of a person, or thermal well-being, expresses a certain degree of satisfaction based on a subjective evaluation of thermal conditions. In addition to individual personal preferences, the evaluation is influenced by physical environmental factors (ASHRAE, 2004). In particular, factors such as air temperature and humidity, wind 
speed, and radiation of heat from the surrounding areas or objects have a thermo-physiological effect on humans (Matzarakis, 2000; Teleghani, 2015). These factors have a major impact on the energy balance of the human body. At different air temperatures, some factors can have a variable impact on humans, for example, wind speed reduces air temperature and thus, at higher air temperatures, the wind creates a comfortable environment, whereas in cold conditions, it increases thermal stress. As a result, people experience feeling cold on the exposed body parts such as face, hands, arms and legs (Ng, 2009; Kang et al., 2013). The microclimate in the complex surface structure of an urban environment results in different conditions of thermal comfort in a restricted space (Gulyas et al., 2006).

The outdoor areas of restaurants, also known as front gardens or summer terraces, become a more important part of the urban space every year. They are public spaces where residents and city visitors spend their free time. In countries with latitudes characterized by a temperate climate, these areas are mainly used to provide refreshment services during the summer. Depending on their variable distribution in urbanized areas, differences in microclimatic conditions may occur (Égerházi et al., 2009). These conditions are determined, for example, by the features of the neighbouring buildings, the surrounding construction density, and the presence of greenery or water elements (Ali-Toudert and Mayer, 2007). As a result, differences in a local urban microclimate can affect its overall thermal comfort and potentially the attractiveness of such an outdoor area. Outdoor areas that do not offer thermal comfort tend to be less frequently used or even avoided by visitors (Égerházi et al., 2009; Vokálová Lörinc, 2015). In extreme cases, visitors may experience thermal stress due to exposure to an excessively cold or warm environment (Mahmoud, 2011).

The present study focuses on the factors influencing the thermal comfort in outdoor areas of restaurants in Central Europe, verified by a case study carried out in the city centre of Pilsen. The aim of the research is to propose and, based on the case study of the city centre of Pilsen, experimentally verify the typology of outdoor areas of restaurants in relation with their location in an urban area and the consequent impact on the thermal comfort of customers. Outdoor restaurant typology will help improve planning as regards their location and provide means to mitigate thermal discomfort.

\subsection{Special characteristics of thermal comfort in a city environment}

Buildings that serve as shading elements have a significant effect on lowering the temperature of air and surfaces in cities on hot summer days (Müller et al., 2014; Lehnert et al., 2018). On such days, shade reduces people's thermal stress and increases their comfort. The arrangement of buildings in street canyons affects the amount of solar energy, as well as wind access and orientation (Jamei, 2016). Differences in exposure to sunlight in the streets can also be seen during the day, depending on their orientation (Ali-Toudert and Mayer, 2007). Streets with an east-west orientation receive more solar energy than north-south streets where the street canyon area is overshadowed most of the day. A seasonal pattern can be identified in the shading of street canyons (Hwang et al., 2011; Armson et al. 2013). In enclosed and shaded areas, it is less likely that people will experience thermal discomfort from excessive heat (Oliveira et al., 2011; Taleghani, 2014). In addition to shielding elements, the thermal environment of a city is also affected by the microclimatic characteristics of the surfaces. In particular, materials of different albedo will alter the surrounding air temperature (Mahmoud, 2011). Furthermore, water elements and water surfaces will affect the environment, as the level of evaporation reduces the surrounding air temperature by $2-4^{\circ} \mathrm{C}$ while increasing the relative humidity ( $\mathrm{Xu}$ et al., 2010).

Plants are as important, as they regulate the urban microclimate, having a cooling effect on the city's green infrastructure, which is dependent on the location and parameters of urban vegetation (Bruse, 2007; Takács et al., 2016; Păcurar, 2017; Milošević et al., 2017). Deciduous trees are especially important, as they form shade in summer and reduce the intensity of sunlight; this can result in the reduction of air temperature by up to $4^{\circ} \mathrm{C}$ and surface temperature by up to $12^{\circ} \mathrm{C}$ (Hewitt, 2009). The evaporation from vegetation is also important for the thermoregulation of the environment, since the solar energy used for the evaporation process is not converted into undesirable heat. Therefore, the presence of grown trees significantly affects the climatic conditions of an urban public space. Evapotranspiration from plants can reduce air temperature in the area by $2-8^{\circ} \mathrm{C}$, but greenery can worsen the dispersion of traffic pollutants in the air due to lower ventilation. In the summer, people experience the highest heat stress in open unshaded squares without greenery, while the more shaded areas, or those with greenery, are felt as more comfortable at high air temperatures (Lau, 2015).

Thermal comfort of the urbanized environment can be assessed using various bioclimatic indices, such as the Predicted Mean Vote Index (Égerházi et al., 2009), or Physiological Equivalent Temperature (Müller et al., 2014). The perception of thermal comfort depends not only on the actual physical condition of the atmosphere (temperature, wind speed, and humidity), but also on the individual sensitivity of the person concerned. The perception 


\section{Typology of Outdoor Seating Areas of Restaurants Based on Factors Influencing Their Thermal Comfort. A Case Study of Pilsen City Centre, Czechia \\ Journal Settlements and Spatial Planning, vol. 10, no. 2 (2019) 131-142}

of the temperature felt is also influenced by the phenomena called alliesthesia (Lindner-Cendrowska and Błażejczyk 2018), e.g. the feeling of thermal discomfort is intensified when moving from an airconditioned area to the outside of a building.

The Beergarden Days Index (BGD) was designed specifically for the assessment of climatefriendly days for the evening use of outdoor restaurants (Toy et al., 2007), in relation to attendance of tourists (Vitt et al., 2015), but it is also used more generally for the evaluation of bioclimatic conditions in the cities (Unger, 1999; Gulyás et al., 2006). This is the number of days in a year when air temperature at 9 p.m. is higher than $20^{\circ} \mathrm{C}$; these days offer warm, comfortable evenings with the possibility of staying outside in a restaurant garden or sitting in public areas without feeling cold (Géczi, 1998).

\subsection{Regulation of thermal comfort in urban public spaces}

The issue of thermal comfort in urban public spaces brings together urbanists and climatologists, who mutually strive to create an environment that is thermally comfortable for people. They use various measures to reduce thermal discomfort in outdoor areas (Teleghani et al., 2015). Comfortable conditions can be achieved by using various spatial arrangements (Ali-Toudert and Mayer, 2007; Bajšanski et al., 2015), appropriate types of materials, greenery (Milošević et al., 2017), and water or technical elements (Smith and Lermore, 2008; Lenzholzer, 2012; Lörinc Vokálová, 2015; Cubillos-González and Castillo-García, 2016). To feel comfortable at high air temperatures, it is important to use shading (plants or artificial elements), evaporation (nozzles spraying water, misting systems), or, if possible, artificially created airflow. Water elements in different forms (fountains, springs, nozzles) are important, as water drops absorb heat from the air and cool the air (Müller et al., 2014). Well-chosen materials with high albedo can reduce the absorption of heat energy and reduce the surrounding temperature. In general, light-colour and shiny surfaces are more reflective than dark and matt ones. On the other hand, places that are not shaded offer better comfort at low temperatures. One way to increase the surrounding temperature is to use a source of air-heating - heat radiation (Lörinc Vokálová, 2015).

At low temperatures, strong winds can be effectively reduced for example, by a greenery barrier, or by placing technical barriers in the direction of wind flow. On the contrary, at high temperatures, ventilated spaces where the wind flow is not restricted provide better thermal comfort (Ali-Toudert and Mayer, 2007). Alternatively, technical sources of wind, such as portable fans, can be used in windless environments or spaces where air flow is restricted
(Kang et al., 2013). These and other similar means improve climatic conditions in the outdoor urban environment and, as a result, people spend more time in public spaces. Specific elements that improve thermal comfort can be installed in outdoor areas of restaurants, where they play an important role, for example, in terms of the number of visitors (Égerházi et al., 2009). The increasing habitability of outdoor public spaces can have a positive impact on the living conditions of citizens and the development of a city centre (Cohen et al., 2013).

\section{STUDY AREA AND METHODS}

\subsection{Specification and climatic characteristics of the study area}

The regional city of Pilsen, situated in the western part of the Czech Republic $\left(49^{\circ} 44^{\prime} \mathrm{N}, 13^{\circ} 23^{\prime} \mathrm{E}\right)$, covers an area of approximately $140 \mathrm{~km}^{2}$. The natural conditions of the city territory are influenced by its location at the confluence of four rivers. The altitude of Pilsen varies between 293 and $452 \mathrm{~m}$ above sea level. Bottoms of the valleys along watercourses have the lowest altitudes, of about $300 \mathrm{~m}$ above sea level (Matušková and Novotná, 2007).

The area designated for research is located in Pilsen city centre, with a high concentration of buildings, covering an area of $0.42 \mathrm{~km}^{2}$ (Figure 1). Within that area, $79.6 \%$ is used for buildings, other constructions and roads, $20 \%$ is covered with greenery and $0.4 \%$ of the area is represented by water bodies. Greenery consists mostly of city parks, which are a climatically important element in the historical centre of the city. Satellite monitoring of the urban landscape confirms their influence on the mitigation of the heat island effect in the summer months (World from Space s.r.o., 2018).

The location of all the outdoor areas of restaurants in the researched area is presented in Fig. 1. A total of 75 outdoor areas were identified, of which 43 are run by restaurants and the remaining 32 are operated by smaller entities, mainly cafés and wine bars. Some 43 outdoor areas of restaurants were included in the evaluation and classification. For research purposes, various types of locations of outdoor areas were included: areas located in courtyards, in streets of different directions, in open areas without any edifices or in places with urban greenery and water features. According to the Quitt's climatic classification of the Czech Republic, the climate of Pilsen city can be classified as moderately warm, with long and dry summers, short and slightly warm transitional periods of spring and autumn, and a very dry winter with shorttime snow cover (Matušková and Novotná, 2007). There is evidence of a general temperature increase compared to the data measured in the $20^{\text {th }}$ century. 
While in the period between 1971 and 2000, the average January temperature was $1.6^{\circ} \mathrm{C}$ and that of July was $18^{\circ} \mathrm{C}$ (Matušková and Novotná, 2007), over the period
2006-2015, the average January temperature was $0.1^{\circ} \mathrm{C}$ and that of July was $20^{\circ} \mathrm{C}$.

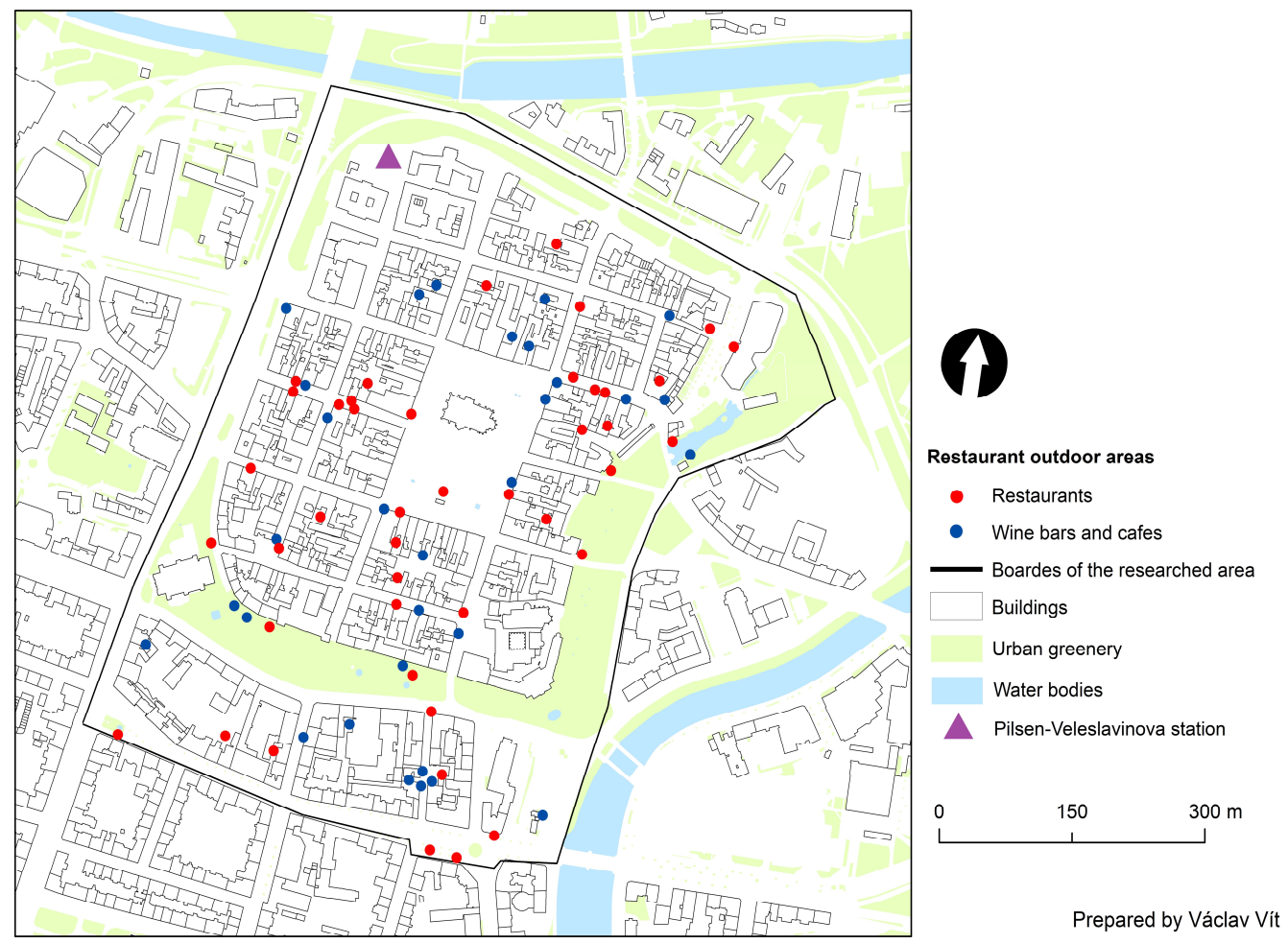

Fig. 1. Location of outdoor areas in the researched territory and their classification according to the type of establishment.

The average number of summer days (defined as days when the maximum temperature reaches $25^{\circ} \mathrm{C}$ or more) is 40-50 (Kopp et al., 2017). The considered study area in the city centre lies predominantly in the urban climate band of the medium-high compact development, in the international classification being referred to as LCZ 2 (Local Climatic Zone 2 - "compact midrise" built type) (Stewart and Oke, 2012). In the Czech Republic, the LCZ 2 zones occur in the area of historic urban centres (Geletič and Lehnert, 2016). Typical for this climatic type is the occurrence of higher temperatures in the evening and night hours, compared to the surrounding "open midrise" built type of the LCZ 5 zones (Geletič and Lehnert, 2016).

For the area of Pilsen city centre, it is possible to use the data from the Pilsen-Veleslavínova station. Based on the data measured in the period of 20092017, we statistically expressed the number of Beergarden Days (BGD). They occur between April and the end of September. The percentage distribution of BGD increases significantly between the first and the second half of May, and continues to rise to a peak in the first half of July, followed by a decline in occurrence. A more marked decline in BGDs occurs between August and the first half of September. BGD tend to be rather rare in April, the first half of May and the end of September. Of the 1,396 days available (April-September), there were 297 days suitable for sitting outside, representing $21.3 \%$. According to these 134 values, the best conditions for sitting outside throughout the year occur from the second half of June to the end of August (Fig. 2).

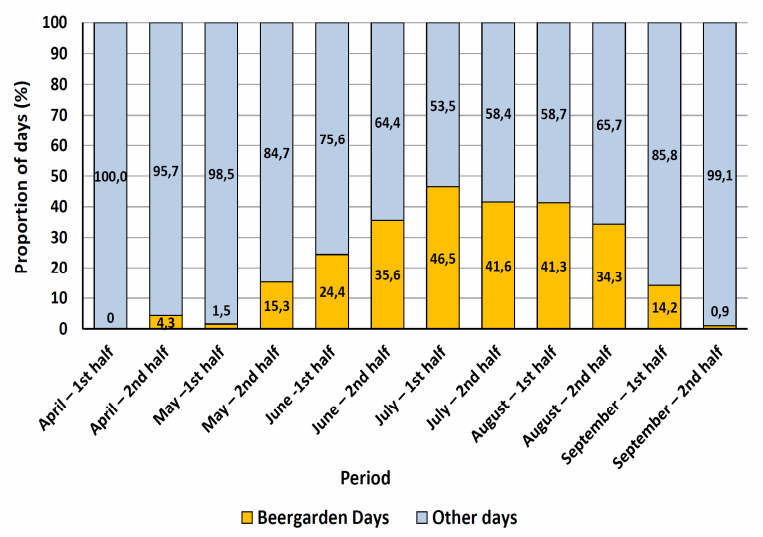

Fig. 2. Percentage of BGD occurrence throughout individual months in Pilsen city centre based on data from the Pilsen-Veleslavínova meteorological station (2009-2017).

\subsection{Creation and verification of typology of outdoor areas of restaurants}

The research was carried out on outdoor areas of restaurants located in the centre of Pilsen city. The study area includes various types of spaces, such as streets, courtyards, squares or parks with urban greenery and water features. Since most of the tourist attractions are located in the city centre, there is a 


\section{Typology of Outdoor Seating Areas of Restaurants Based on Factors Influencing Their Thermal Comfort. A Case Study of Pilsen City Centre, Czechia \\ Journal Settlements and Spatial Planning, vol. 10, no. 2 (2019) 131-142}

higher number of restaurants offering outdoor seating located here. For the purpose of the study, a field survey was carried out in July 2017, which first documented the location of all outdoor areas of restaurant facilities in the specified area of the city centre. From 43 outdoor restaurants registered in this survey, 14 were subsequently selected for detailed monitoring; the main criterion for selection was the difference in the spatial characteristics of their outdoor areas. The research consisted in our own detailed survey on the conditions and equipment of the selected areas as well as the method of conducting expert interviews with the owners and managers of the restaurants. The research questions were focused on the availability of equipments for improving thermal comfort and the influence of weather and microclimate on the operation of restaurants. The means identified as options for comfort improvement were chosen and classified according to the methodology of Lörinc Vokálová (2015), who summarizes the possible causes of thermal discomfort and the means for improving the conditions. The creation of this classification of means available for the reduction of thermal discomfort (Lörinc Vokálová, 2015) was based on urban climate studies (Smith and Lermore, 2008; Lenzholzer, 2012; Kang et al., 2013). For the purpose of our study, we further supplemented this classification with other studies (Ali-Toudert and Mayer, 2007; Égerházi et al., 2009).

The findings from the field survey were summarized in a typology of outdoor areas according to their location. The proposed types were subsequently validated by their differences in the availability of comfort-enhancing equipment and the values of selected meteorological elements measured. Measurements were carried out on 15 August 2017 between 16:00 and 17:30 using a portable meteorological device, the Kestrel 5000, and the infrared thermometer Extech Dual Laser 30. The measurement time was chosen to capture the highest air temperatures of the sunny summer day. However, the measurements at each individual outdoor area were, performed gradually over a time interval during which air temperature changed only slightly. During this measuring period, the air temperature in the city centre increased by $1^{\circ} \mathrm{C}$ at the Pilsen-Veleslavínova station, in almost windless conditions. The measured values included the relative air humidity, air temperature at table height $(80 \mathrm{~cm})$, the temperature of the surface (floor) under a shading object and the temperature of an unshaded surface at a distance of $2 \mathrm{~m}$ from the shading object. Three consecutive measurements were made within one minute for each individual surface; the resulting value assigned to each type is the arithmetic mean of the measured data. Since the portable meteorological device cannot measure mean radiant temperature, we did not use standard bioclimatological indices such as the Physiological Equivalent Temperature (Höppe, 1999; Müller et al., 2014). The bioclimatic conditions were not influenced by wind at the time of the experiment.

\section{RESULTS AND DISCUSSION}

\subsection{Typology of outdoor seating areas of restaurants based on their location}

The location of outdoor areas of restaurants in the urban structure is the key factor when categorizing urban areas from the perspective of thermal comfort.

The microclimate of areas is influenced by factors that play a significant role in the proposed typology (structure of the surrounding surfaces, types of building, presence of greenery or water elements). Based on the field survey in the city centre of Pilsen, a classification into four types of outdoor areas was proposed based on the location of these areas, which influences their character and consequently their potential microclimatic properties (Table 1, Fig. 3).

Table 1. Typology of outdoor seating areas of restaurants based on their location.

\begin{tabular}{|c|c|c|}
\hline Typology & $\begin{array}{l}\text { Location of the outdoor } \\
\text { area }\end{array}$ & Environment of the outdoor area \\
\hline $\begin{array}{l}\text { Type } 1-\text { Square } \\
\text { restaurant }\end{array}$ & $\begin{array}{l}\text { Located on open ground } \\
\text { with so called "grey" } \\
\text { infrastructure }\end{array}$ & $\begin{array}{l}\text { Areas located on open squares or large pedestrian zones, surrounded by low } \\
\text { evapotranspiration surfaces (paving, sidewalks, roads), with a minor proportion } \\
\text { of green areas and water features. }\end{array}$ \\
\hline $\begin{array}{l}\text { Type } 2 \text { - Courtyard } \\
\text { restaurant }\end{array}$ & In a courtyard & $\begin{array}{l}\text { Areas in public courtyards, surrounded by multi-storey buildings at least on } \\
\text { three sides. There may be some greenery or water features. }\end{array}$ \\
\hline $\begin{array}{l}\text { Type } 3 \text { - Park } \\
\text { restaurant }\end{array}$ & $\begin{array}{l}\text { In open spaces with "blue- } \\
\text { green" infrastructure }\end{array}$ & $\begin{array}{l}\text { Areas located in park and urban greenery, in recreational areas of the urban } \\
\text { environment, and, at the same time, close to water areas or water elements. }\end{array}$ \\
\hline $\begin{array}{l}\text { Type } 4 \text { - Street } \\
\text { canyon restaurant }\end{array}$ & In a street canyon & $\begin{array}{l}\text { A variable type that combines features of types } 1 \text { and } 2 \text {. Areas located in } \\
\text { streets with a north-south or west-east orientation, adjacent to the surrounding } \\
\text { buildings. Mostly located on hard surfaces with low evapotranspiration, } \\
\text { without urban greenery or water elements. }\end{array}$ \\
\hline
\end{tabular}



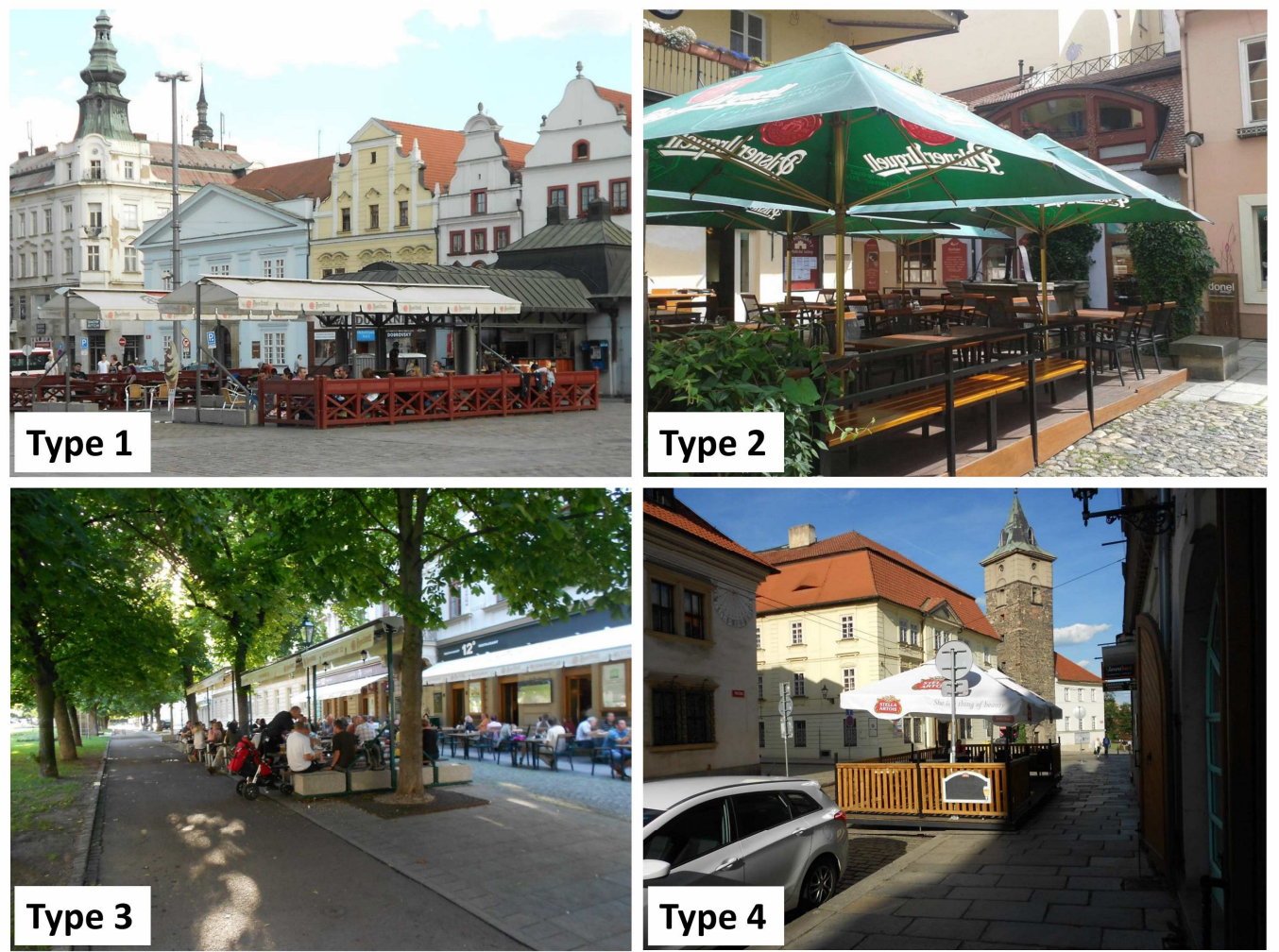

Fig. 3. Examples of types of outdoor seating areas of restaurants based on their location (Table 1): Type 1 - Square restaurant, Type 2 - Courtyard restaurant, Type 3 - Park restaurant, Type 4 - Street canyon restaurant.

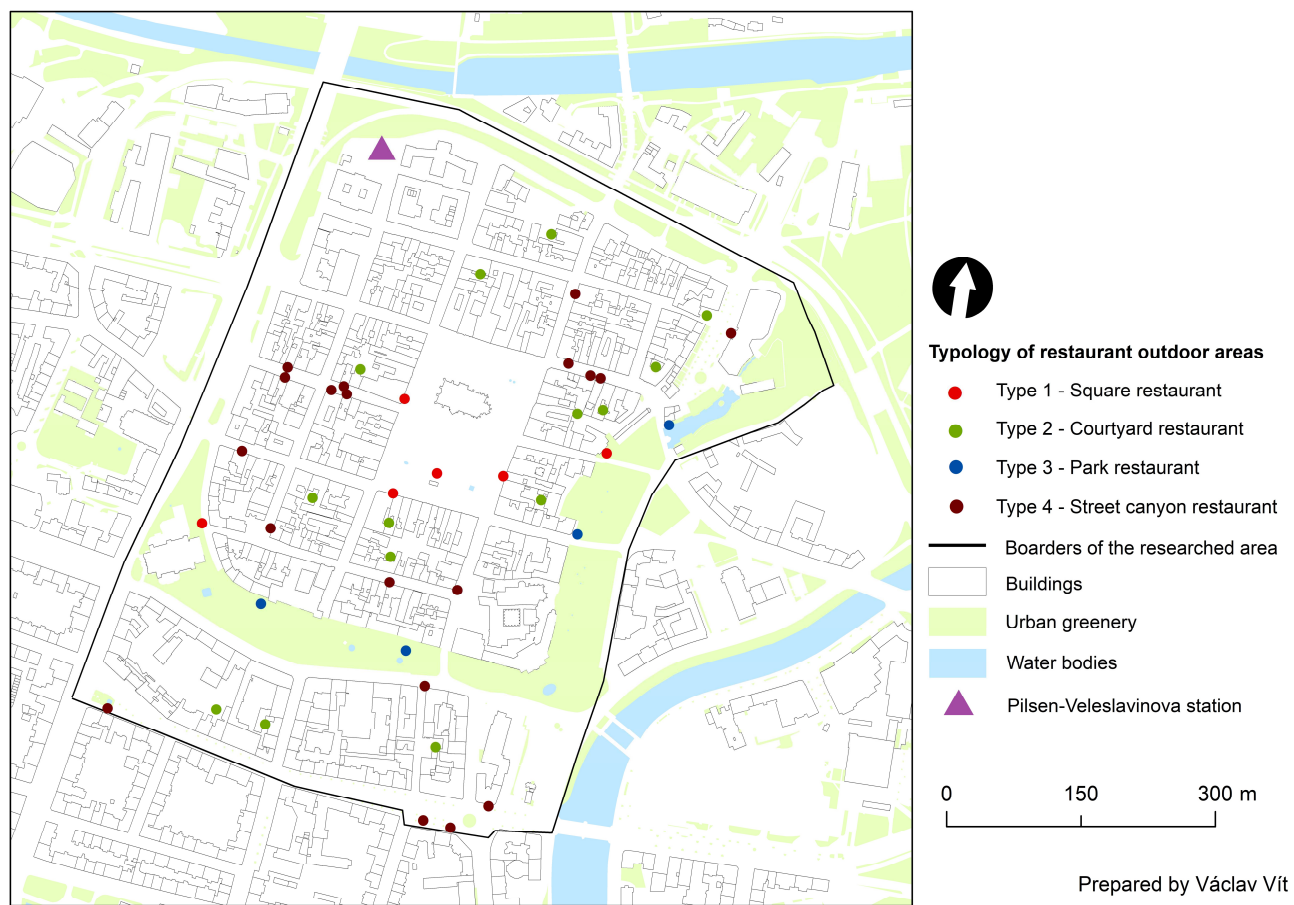

Fig. 4. Outdoor areas of restaurants in the researched territory classified into individual types.

3.2. Comparison of types according to the means necessary for thermal comfort improvement

In order to improve thermal comfort conditions for their customers, outdoor restaurants use various technical means, partly related to their location in a specific microclimate. This way, discomfort caused by excessive heat, cold, and wind can be successfully minimized. Information obtained from specialized literature and field research is summarized in Table 2. The table presents, in an orderly manner, the system of 


\section{Typology of Outdoor Seating Areas of Restaurants Based on Factors Influencing Their Thermal Comfort. A Case Study of Pilsen City Centre, Czechia \\ Journal Settlements and Spatial Planning, vol. 10, no. 2 (2019) 131-142}

means used by the selected restaurants to improve

thermal conditions for their customers.

Table 2. Conditions and means available for the reduction of thermal discomfort (prepared by authors based on: Ali-Toudert and Mayer, 2007; Égerházi et al., 2009; Lörinc Vokálová, 2015).

\begin{tabular}{|c|c|c|c|}
\hline \multirow{2}{*}{$\begin{array}{l}\text { Cause of } \\
\text { discomfort }\end{array}$} & \multirow{2}{*}{ Reducing discomfort } & \multicolumn{2}{|c|}{ Conditions and means available for the reduction of discomfort } \\
\hline & & The influence of the surrounding area & Technical means \\
\hline \multirow{3}{*}{ A Heat } & Limiting solar radiation & $\begin{array}{l}\text { A1 Shading by buildings } \\
\text { A2 Shading by trees }\end{array}$ & $\begin{array}{l}\text { A3 Parasols } \\
\text { A4 Retractable awnings } \\
\text { A5 Sunshades with fixed construction }\end{array}$ \\
\hline & Evapotranspiration & $\begin{array}{l}\text { A6 Water elements and water areas } \\
\text { A7 Surrounding urban greenery }\end{array}$ & \\
\hline & Ventilation & A8 Aeration of buildings & A9 Electrical ventilators \\
\hline \multirow[b]{4}{*}{ B Cold } & Increasing solar radiation & B1 Increase in direct sunlight & \\
\hline & Additional heat source & & B2 Gas or electric heaters \\
\hline & $\begin{array}{l}\text { Increase in the insulation } \\
\text { layer }\end{array}$ & & B3 Blankets and seat cushions \\
\hline & $\begin{array}{l}\text { Thermal insulation by } \\
\text { covering }\end{array}$ & & $\begin{array}{l}\text { B4 Retractable awnings and sunshades } \\
\text { B5 Fixed construction - covering from a side }\end{array}$ \\
\hline C Wind & Lowering ventilation & $\begin{array}{l}\text { C1 Lee of buildings } \\
\text { C2 Lee of greenery }\end{array}$ & C3 Fixed construction - wind barriers \\
\hline
\end{tabular}

Discomfort from excessive heat can be reduced by shielding, namely a combination of technical means and shading from buildings and greenery. Parasols and awnings, and possibly fixed structures, which can be supplemented with side and front screens, are used as technical means. Other cooling features include evaporation from greenery or water elements as well as air circulation (natural/artificial). In cold conditions, restaurants benefit from a location in a space with more direct sunlight. Alternatively, they use additional heat sources, or they provide customers with means to increase the insulation layer. Shielding elements can also be used for heat insulation, in the best case, fixed structures with the possibility of adding side walls that prevent heat leakage back to the outside. Furthermore, fixed structures with screens are advantageous to eliminate wind effects. In the researched area in the centre of Pilsen, differences were found in the conditions according to location and the means for reducing thermal discomfort (Tables 3 and 4, Fig. 5).

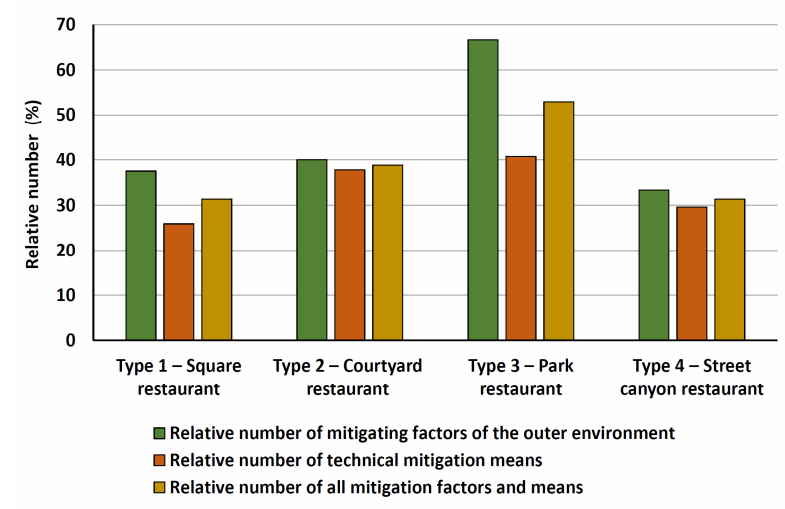

Fig. 5. Relative number of factors that influence and the means that reduce thermal discomfort in individual types of restaurant outdoor areas.
Areas belonging to Type 1 (Square restaurant) have the lowest number of technical means; they are rather affected by their location. An open space position allows for more solar energy to be accumulated during the day (B1), which can be an advantage in the case of a cool day/evening. The open space also allows for free air circulation (A8); as a result, the wind cools customers on a warm day. Retractable awnings for shading are the only technical means used (A4).

Depending on their location, Type 2 (Courtyard restaurant) and Type 3 (Park restaurant) areas, generally, have more water elements (A6) and greenery around them (A2, A7, C2). At the same time, they are also better equipped with technical features. Only the courtyard areas were equipped with portable fans (A9) enabling artificial ventilation. One outdoor area belonging to Type 3 was equipped with a fixed shielding element providing side shading; this allows for heat insulation (B5) in cool weather and eliminates the effects of wind $\left(\mathrm{C}_{3}\right)$. In the case of both types, specific elements for increasing heat, especially gas and electric heaters, are used (B2). All Type 2 examined areas are shaded by buildings (A1), which also restrict air ventilation ( $\mathrm{C} 2)$. It is the case in which technical shading elements also include retractable awnings (A4) and sunshades (A3).

Areas located in street corridors (Type 4 Street canyon restaurant) use the benefits of their location, such as the shade from the neighbouring buildings (A1) and limited ventilation as wind blows are blocked by the constructions. (C1). Similarly to Type 1 , there are no water elements or greenery in the adjacent areas. Technical shading is provided by awnings (A4).

According to this comparison, the most comfortable areas are those located in the urban greenery (Type 3); the areas located in courtyards (Type 
2) offer slightly less favourable conditions. These two types can be expected to have only minor changes in comfort throughout the day, as greater shading and the presence of greenery will stabilize air temperature. Type 1 and Type 4 areas are less comfortable; their thermal conditions are almost identical and depend on the availability of technical elements. At the same time, they are likely to experience greater changes in thermal comfort during the day depending on the position of the sun.

Table 3. Number of conditions influencing and means reducing thermal discomfort in individual types of areas (description of conditions and means according to Table 2).

\begin{tabular}{|c|c|c|c|c|c|c|c|c|c|c|c|c|c|c|c|c|c|c|}
\hline \multirow{2}{*}{\multicolumn{2}{|c|}{$\begin{array}{c}\begin{array}{c}\text { Factors } \\
\text { relieving } \\
\text { discomfort }\end{array} \\
\begin{array}{c}\text { Cause of } \\
\text { discomfort }\end{array}\end{array}$}} & \multicolumn{8}{|c|}{ Influence of the surrounding area } & \multicolumn{9}{|c|}{ Technical means } \\
\hline & & \multicolumn{5}{|c|}{ A heat } & \multirow{2}{*}{$\begin{array}{c}\text { B Cold } \\
\text { B1 }\end{array}$} & \multicolumn{2}{|c|}{ C Wind } & \multicolumn{3}{|c|}{ A Heat } & \multicolumn{3}{|c|}{ B Cold } & \multicolumn{3}{|c|}{ C Wind } \\
\hline Type & $\begin{array}{l}\text { Number } \\
\text { of areas }\end{array}$ & A1 & A2 & A6 & A7 & A8 & & C1 & $\mathrm{C2}$ & A3 & A4 & A5 & A9 & $\mathbf{B 2}$ & $\mathbf{B 3}$ & B4 & B5 & C3 \\
\hline 1 & 3 & 2 & 0 & 1 & 0 & 2 & 3 & 1 & 0 & 0 & 3 & 0 & 0 & 0 & 1 & 3 & 0 & 0 \\
\hline 2 & 5 & 5 & 1 & 1 & 3 & 0 & 0 & 5 & 1 & 3 & 3 & 0 & 2 & 1 & 4 & 4 & 0 & 0 \\
\hline 3 & 3 & 2 & 3 & 2 & 3 & 1 & 0 & 2 & 3 & 0 & 2 & 1 & 0 & 2 & 2 & 2 & 1 & 1 \\
\hline 4 & 3 & 3 & 0 & 0 & 0 & 2 & 0 & 3 & 0 & 0 & 3 & 0 & 0 & 0 & 2 & 3 & 0 & 0 \\
\hline
\end{tabular}

Table 4. Average number of factors that influence and means that reduce thermal discomfort in individual types of restaurant outdoor areas (Type 1 - Square restaurant, Type 2 - Courtyard restaurant, Type 3 - Park restaurant, Type 4 - Street canyon restaurant).

\begin{tabular}{|l|l|c|c|c|c|}
\hline Type & Location of the outdoor area & $\begin{array}{c}\text { Number of areas } \\
\text { tested }\end{array}$ & $\begin{array}{c}\text { Average number of } \\
\text { impact factors from } \\
\text { the surrounding } \\
\text { areas }\end{array}$ & $\begin{array}{c}\text { Average number of } \\
\text { technical means }\end{array}$ & $\begin{array}{c}\text { number of } \\
\text { influence factors } \\
\text { and means }\end{array}$ \\
\hline 1 & $\begin{array}{l}\text { Area on open ground with } \\
\text { grey infrastructure }\end{array}$ & 3 & 3.0 & 2.3 & 5.3 \\
\hline 2 & In courtyards & 5 & 3.2 & 3.4 & 6.7 \\
\hline 3 & $\begin{array}{l}\text { In open spaces with blue-green } \\
\text { infrastructure }\end{array}$ & 3 & 5.3 & 3.7 & 9.0 \\
\hline 4 & In a street canyon & 3 & 2.7 & 2.7 & 5.3 \\
\hline
\end{tabular}

\subsection{Comparing the types of areas based on experimental measurements and views of managers}

According to the experimental measurement of meteorological elements, the individual types of areas differ in temperature and humidity characteristics (Fig. 6).

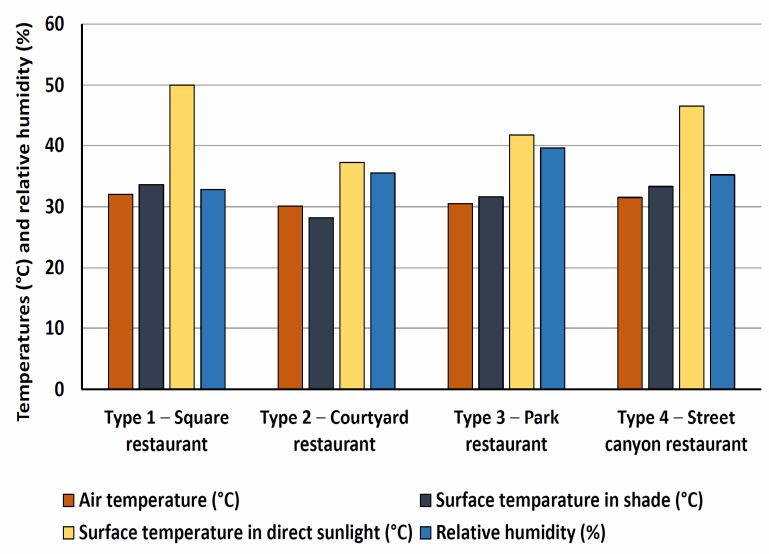

Fig. 6. Average values of selected meteorological elements according to individual types of location of outdoor areas of restaurants measured on 15 August 2017 between 4:00-5:30 pm.
Type 1 - Square restaurant exhibited the highest air and surface temperatures, along with the lowest relative humidity of all types. In contrast, Type 2 - Courtyard restaurant showed the lowest air and surface temperatures and Type 3 - Park restaurant showed the highest air humidity. Type 4 - Street canyon restaurant had similar temperatures as Type 1, and the humidity of the air was closer to Type 2. The experimental measurements revealed differences among the three types of areas; Type 4 could be grouped with Type 1 because their air and surface temperatures are similar.

According to the managers interviewed, on cool days the areas classified as Type 1 record higher attendance than the shaded areas of Type 2 and 3. Type 4 areas are comfortable during afternoons on sunny days if they are shaded and have natural air circulation. Type 2 (courtyard) areas are less well attended on days with very warm conditions and no air circulation. Courtyard areas are also better protected against combinations of rainfall and wind. Attendance at Type 2 areas decreases by $40 \%$ on rainy days in comparison to sunny days, whilst at Types 1 and 4 it decreases by up to $70 \%$. 


\section{Typology of Outdoor Seating Areas of Restaurants Based on Factors Influencing Their Thermal Comfort. A Case Study of Pilsen City Centre, Czechia \\ Journal Settlements and Spatial Planning, vol. 10, no. 2 (2019) 131-142}

\subsection{Discussion of typology}

The aim of this article is to focus on the issue of human thermal comfort and microclimatic conditions in cities, using the example of outdoor areas of restaurants in the centre of Pilsen. The results are consistent with the findings of studies on thermal comfort in an urban landscape (Ali-Toudert and Mayer 2007; Müller et al., 2014). Thermal comfort can be influenced by the location of the outdoor area in the urban space, and the presence of greenery or water elements. These factors can determine whether the area is suitable for staying in or whether it is likely to be used less due to thermal stress (Égerházi et al., 2009). The stress occurs when a person feels excessively cold or hot in a given environment (Lindner-Cendrowska and Błażejczyk, 2018). Appropriate design and correct placement within the area in question can mitigate the thermal stress. In this study, a typology of outdoor restaurant areas was created based on their location in the centre of Pilsen, that is mainly in an area of medium-high building density (LCZ 2: Stewart and Oke, 2012). Based on the proposed classification four categories were identified: open areas with grey infrastructure (Type 1 - Square restaurant), in courtyards (Type 2 - Courtyard restaurant), in open spaces with blue-green infrastructure (Type 3 - Park restaurant) and in street canyons (Type 4 - Street canyon restaurant). The relevance of the typology was verified by establishing whether the types differ by the means they use for enhancing comfort and by the values of selected meteorological elements measured.

According to the data obtained from the experimental measurements, Type 1 appears to be the warmest, while type 2 the coolest; the highest relative humidity was measured in Type 3 . Type 4 is similar to Type 1 in terms of air and surface temperature values and to Type 2 in terms of relative humidity values. The proposed typology was largely confirmed by the experimental measurements. However, the disadvantage is the nature of measurement; it was performed only on one day in the summer and, therefore, it is necessary to further verify the results by additional microclimatic monitoring. Some types may vary considerably over the year: for example, the shade of buildings changes during the year depending on the height of the sun, and consequently the values of each type may vary (Hwang et al., 2011).

\section{CONCLUSIONS}

Understanding the process of climatology allows us to perceive what happens around us, and offers ways to prevent some of the negative effects of climate variations, or use such variations to our advantage (Popescu and Luca, 2017). There is a growing need for adaptation to climate change in Central European cities (Cubillos-González and Castillo-García, 2016). Heat waves bring higher potential sales of beverages or ice cream (Vít, 2018), but, at the same time, they place higher demands on the creation of a temperature-comfortable environment, especially in the outdoor areas of bars and restaurants (Égerházi et al., 2009). The present study presents a basic overview of the so far neglected issue of thermal comfort in the outdoor areas of restaurants. The proposed typology based on the location and characteristics of outdoor areas can be used for the basic classification of the conditions of individual businesses.

Field research closely monitored fourteen outdoor areas in the centre of Pilsen. An overview of the means used to improve conditions was created, i.e. those that eliminate excessive heat, cold or wind effects. Based on the research findings, differences in the number and nature of means for improving thermal comfort were identified for each type. After differentiating the resources and means available to each individual category, Type 3 (Park restaurant) has been found the most comfortable due to the advantageous combination of technical means and location. Similarly, Type 2 (Courtyard restaurant) areas manifest comparable features, but the number of means available is slightly lower. Type 1 (Square restaurant) and Type 4 (Street canyon restaurant) seem to be the least comfortable.

Climatic conditions affect the attendance of outdoor restaurants (Égerházi et al., 2009) or even the choice of meals (Bujisic et al., 2017). According to the restaurant managers in Pilsen, outdoor areas are used 6-7 months a year from April to September or October. After the start of the season, sales increase by $15-85 \%$, but the main reason for this is the increase in the number of seats throughout the business premises and generally higher attendance in the warm half of the year. Therefore, restaurant managers can use knowledge of the impact of location for the improvement of thermal comfort of their customers, and consequently for their commercial success. The typology created, which includes restaurant location, climate effects and means of mitigating negative effects, is a guide to the design of space in terms of climatic conditions and the possibilities to address the local climate. It can also serve as a basis for assessing the means available for the enhancement of comfort of restaurant customers in temperate climate cities.

We can summarize the important results for restaurant managers. The location of the outdoor area of a restaurant influences its daily operation. Depending on the type of outdoor area of the restaurant, appropriate means to mitigate discomfort should be chosen. Urban greenery is the best protector against thermal stress in the outdoor areas of restaurants. 
It is important to monitor the microclimatic conditions in cities, to consider them when designing outdoor restaurants and to try to improve them in relation to climate change. To attract customers to outdoor seating areas of restaurants, it will be necessary to start paying attention to their basic physiological needs, e.g. the feeling of comfort affected by temperature, humidity and airflow. The number of customers attending the considered areas and all other outdoor public areas may be affected by these factors, fact that was also confirmed by restaurant managers in the city of Pilsen. Meteorological conditions also have an influence on other factors such as beverage sales. The demonstration of dependence has proved to be difficult due to the presence of other factors affecting attendance. The issue can be further explored by studying the relationship between periods of rainfall and restaurant attendance, or the impact of indoor air conditioning on the differences between outdoor and indoor restaurant environments.

\section{ACKNOWLEDGEMENTS}

This research was supported by the Technology Agency of the Czech Republic, Grant ÉTA TL01000498 "Revitalization of city centres and other public spaces in the Czech Republic: Problems, foreign inspiration, possible solutions".

\section{REFERENCES}

Ali-Toudert F., Mayer H. (2007), Thermal comfort in an east-west oriented street canyon (Germany) under hot summer conditions. Theoretical and Applied Climatology, 87, 223-237. DOI: https://doi.org/10.1007/s00704-005-0194-4.

Armson D., Rahman M., Ennos A. (2013), A Comparison of the Shading Effectiveness of Five Different Street Tree Species in Manchester, UK. Arboriculture \& Urban Forestry, 39, 157-164.

ASHRAE (2004), Thermal environmental conditions for human occupancy. ANSI/ASHRAE Standard 552004. American Society of Heating, Refrigerating and Air-Conditioning Engineers, Atlanta. ISSN 1041-2336.

Bajšanski I. V., Milošević D. D., Savić S. M. (2015), Evaluation and improvement of outdoor thermal comfort in urban areas on extreme temperature days: Applications of automatic algorithms. Building and Environment, 94(2), 632-643. DOI: https://doi.org/ 10.1016/j.buildenv.2015. 10. 019

Bruse M. (2007), Simulating human thermal comfort and resulting usage patterns of urban open spaces with a Multi-Agent Systém. In: Wittkopf S., Tan B. K. (eds) Proceedings of the 24th International Conference on Passive and Low Energy Architecture PLEA, 699-706.

Bujisic M., Bogicevic V., Parsa H. G. (2017), The effect of weather factors on restaurant sales. Journal of
Foodservice Business Research, 20(3), 350-370. DOI: https://doi.org/10.1080/15378020.2016.1209723

Cohen P., Potchter O., Matzarakis A. (2013), Human thermal perception of Coastal Mediterranean outdoor urban environments. Applied Geography, 37, 110. DOI: https://doi.org/10.1016/j.apgeog.2012. 11. 001. Cubillos-González R.-A., Castillo-García L.-S. (2016), The climate as a key factor of public life in European cities. ArchNet International Journal of Architectural Research, 10 (1), 358-368. DOI: http://dx.doi.org/10.26687/archnet-ijar.v10i1.825

Égerházi L. A., Kántor N., Gulyás Á. (2009), Investigation of human thermal comfort by observating the utilization of open-air terraces in catering places - a case study in Szeged. Acta climatologica et chorologica, Universitatis Szegediensis, 42-43, 29-37.

Géczi R. (1998), Human bioclimatological features of Cluj. Acta universitatis lodziensis, Folia geographica physica, 3, 135-144.

Geletič J., Lehnert M. (2016), GIS-based delineation of local climate zones: The case of mediumsized Central European cities. Moravian Geographical Reports, 24(3), 2-12. DOI: https://doi.org/10.1515/ mgr-2016-0012

Geletič J., Vysoudil M. (2012), Analysis of Surface Temperatures in Urban and Suburban Landscape from Satellite Thermal Images: A Case Study of Olomouc and Its Environs, Czech Republic. Moravian Geographical Reports, 20(1), 2-15.

Gulyas A., Unger J., Matzarakis A. (2006), Assessment of the microclimatic and human comfort conditions in a complex urban environment: Modelling and measurements. Building and Environment, 41, 1713-1722. DOI: https://doi.org/10.1016/j.buildenv. 2005.07.001

Hewitt C. N., Jackson A. V. (eds) (2009), Atmospheric science for environmental scientists. Wiley-Blackwell, Oxford. ISBN 978-1-4051-5690-5.

Höppe P. (1999), The physiological equivalent temperature - a universal index for the biometeorological assessment of the thermal environment. International Journal of Biometeorology, 43, 71-75. DOI: https://doi.org/10.1007/s004840 050118.

Hwang R. L., Lin T. P., Matzarakis A. (2011), Seasonal effects of urban street shading on long-term outdoor thermal comfort. Building and Environment, 46(4), 863-870. DOI: https://doi.org/10.1016/ j.buildenv.2010.10.017

Jamei E., Rajagopalan P., Jamei Y. (2016), Review on the impact of urban geometry and pedestrian level greening on outdoor thermal comfort. Renewable and Sustainable Energy Reviews, 54, 10021017. DOI: https://doi.org/10.1016/j.rser.2015.10.104

Kang K., Song D., Schiavon S. (2013), Correlations in thermal comfort and natural wind. Journal of 


\section{Typology of Outdoor Seating Areas of Restaurants Based on Factors Influencing Their Thermal Comfort. A Case Study of Pilsen City Centre, Czechia \\ Journal Settlements and Spatial Planning, vol. 10, no. 2 (2019) 131-142}

Thermal Biology, 38, 419-426. DOI: https://doi.org/ 10.1016/j.jtherbio.2013.06.001

Kopp J., Raška P., Vysoudil M., Ježek J., Dolejš M., Veith T., Frajer J., Novotná M., Hašová E. (2017), Ekohydrologický management mikrostruktur městské krajiny (Ecohydrological management of the urban landscape's microstructures). University of West Bohemia, Pilsen [Book in Czech]. ISBN 978-80261-0719-4.

Lau K., Lindberg F., Rayner D. (2015), The effect of urban geometry on mean radiant temperature under future climate change: a study of three European cities. International Journal of Biometeorology, 59, 799-814. DOI: https://doi.org/10.1007/s00484-014-0898-1

Lehnert M., Kubeček J., Geletič J., Jurek M., Frajer J. (2018), Identifying hot and cool spots in the city centre based on bicycle measurements: the case of Olomouc, Czech Republic. Geographia Pannonica, 22(4), 230-240. DOI: https://doi.org/10.5937/gp22-19750

Lenzholzer S. (2012), Research and design for thermal comfort in Dutch urban squares. Resources, Conservation and Recycling, 64, 39-48, DOI: https://doi.org/10.1016/j.resconrec.2011.06.015

Lindner-Cendrowska K., Błażejczyk K. (2018), Impact of selected personal factors on seasonal variability of recreationist weather perceptions and preferences in Warsaw (Poland). International Journal of Biometeorology, 62, 113-125. DOI: https://doi.org/10.1007/soo484-016-1220-1

Luca O. (2017), Considerations on climate strategies and urban planning: Bucharest case study. Theoretical and Empirical Researches in Urban Management, 12(1), 53-59.

Mahmoud A. H. A. (2011), Analysis of the microclimatic and human comfort conditions in an urban park in hot and arid regions. Building and Environment, 46, 2641-2656. DOI: https://doi.org/ 10.1016/j.buildenv.2011.06.025

Matušková A., Novotná M. (eds) (2007), The Geography of Plzeň. University of West Bohemia, Pilsen. ISBN 978-80-7043-583-0.

Matzarakis A., Mayer H. (2000), Atmosferic conditions and human thermal comfort in urban areas. In: 11th Seminar on Environmental Protection: Environment and Health. Thessaloniki, Greece, 155-166.

Milošević D. D., Bajšanski I. V., Savić S. M. (2017), Influence of changing trees locations on thermal comfort on street parking lot and footways. Urban Forestry \& Urban Greening, 23, 113-124. DOI: https://doi.org/10.1016/j.ufug.2017.03.011

Müller N., Kuttler W., Barlag AB. (2014), Counteracting urban climate change: adaptation measures and their effect on thermal comfort. Theoretical and Applied Climatology, 115, 243-257. DOI: https://doi.org/10.1007/s00704-013-0890-4

Ng E. (2009), Policies and technical guidelines for urban planning of high-density citis - air ventilation assessment (AVA) of Hong Kong. Building and Environment, 44, 1478-88. DOI: https://doi.org/ 10.1016/j.buildenv.2008.06.013

Oliveira S., Andrade H., Vaz T. (2011), The cooling effect of green spaces as a contribution to the mitigation of urban heat: A case study in Lisbon. Building and Environment 46, 2186-2194. DOI: https://doi.org/10.1016/j.buildenv.2011.04.034

Păcurar B.-N. (2017), How Green are Romania's Cities? A Quarter - Century of Green Area Policy. Journal of Settlements and Spatial Planning, 8(1), 7177. DOI: https://doi.org/10.24193/JSSP.2017.1.06 Popescu A. L., Luca O. (2017), Built environment and climate change. Theoretical and Empirical Researches in Urban Management, 12(4), 52-66.

Slach O., Ježek J. (2015), Czechia. disP - The Planning Review, 51(1), 28-29.

Smith C., Lermore G. (2008), Designing urban spaces and buildings to improve sustainability and quality of life in a warmer world. Energy Policy, 36(12), 4558-4562. DOI: https://doi.org/10.1016/j.enpol. 2008.09.011

Stewart I. D., Oke T. R. (2012), Local climate zones for urban temperature studies. Bulletin of the American Meteorological Society, 93(12), 1879-1900. DOI: https://doi.org/10.1175/BAMS-D-11-00019.1

Takács Á., Kiss M., Gulyás Á., Tanács E., Kántor N. (2016), Solar permeability of different tree species in Szeged, Hungary. Geographica Pannonica, 20(1), 32-41. DOI: https://doi.org/10.5937/GeoPan $1601032 \mathrm{~T}$

Teleghani M., Kleerekoper L., Tenpierik MJ., van den Dobbelsteen AAJF. (2015), Oudoor thermal comfort within five different urban forms in the Netherlands. Building and Environment, 83, 6578. DOI: https://doi.org/10.1016/j.buildenv.2014.03. 014.

Toy S., Yilmaz S., Yilmaz H. (2007), Determination of bioclimatic comfort in three different land uses in the city of Erzurum, Turkey. Building and Environment, 42(3), 1315-1318. DOI: https://doi.org/ 10.1016/j.buildenv.2005.10.031

Unger J. (1999), Comparisons of urban and rural bioclimatological conditions in the case of a CentralEuropean city. International Journal of Biometeorology, 43(3), 139-144. DOI: https://doi.org/ 10.1007/s004840050129

Vít V. (2018), Klimatologické aspekty venkovních ploch restaurací v centru Plzně (Climatological aspects of outdoor areas of restaurants in the centre of Pilsen). University of West Bohemia, Pilsen. [Bachelor's thesis in Czech].

Vitt R., Gulyás Á., Matzarakis A. (2015), Temporal Differences of Urban-Rural Human Biometeorological Factors for Planning and Tourism in Szeged, Hungary. Advances in Meteorology, 2015, Article ID 987576, 18. DOI: https://doi.org/10.1155/2015/987576 
Vokálová Lörinc E. (2015), Člověk a jeho komfort ve veřejném prostoru ve vztahu ke klimatickým podmínkám - Př́klady využití regionálního klimatu ve veřejných prostorech evropských měst (Man and his Comfort in the Public Space in relation to Climatic Condition - Examples of Using Regional Climate in Public Spaces of European Cities). In: Holubec P. (ed.) Člověk, stavba a územní plánování 8. The Czech Technical University in Prague, Prague, 220-232. [Paper in Czech]. ISBN 978-80-0105655-4.
World from Space s.r.o. (2018), Satelitní monitoring Plzeň 2018. Pilotní projekt. Shrnutí poznatkủ (Satellite monitoring Pilsen 2018. Pilot project. Summary). World from Space s.r.o., Brno, Czechia [Report in Czech, online]. URL: https://smartcity.plzen.eu/wp-content/uploads/ 2018/11/Zprava_PLZE\%C5\%87.pdf. Accessed on 15.10.2019.

Xu J., Wei Q., Huang X., Zhu X., Li G. (2010), Evaluation of human thermal comfort near urban waterbody during summer. Building and Environment, 45, 1072-1080. DOI: https://doi.org/10.1016/ j.buildenv.2009.10.025 